\title{
The Influence of Component Stiffness on the Structure of Multithread, Fancy Bouclé Yarn
}

DOI:

$10.1177 / 1528083718801365$

\section{Document Version}

Accepted author manuscript

Link to publication record in Manchester Research Explorer

\section{Citation for published version (APA):}

Alshukur, M., Fotheringham, A., \& Gong, R. (2018). The Influence of Component Stiffness on the Structure of Multithread, Fancy Bouclé Yarn. Journal of Industrial Textiles. https://doi.org/10.1177/1528083718801365

\section{Published in:}

Journal of Industrial Textiles

\section{Citing this paper}

Please note that where the full-text provided on Manchester Research Explorer is the Author Accepted Manuscript or Proof version this may differ from the final Published version. If citing, it is advised that you check and use the publisher's definitive version.

\section{General rights}

Copyright and moral rights for the publications made accessible in the Research Explorer are retained by the authors and/or other copyright owners and it is a condition of accessing publications that users recognise and abide by the legal requirements associated with these rights.

\section{Takedown policy}

If you believe that this document breaches copyright please refer to the University of Manchester's Takedown Procedures [http://man.ac.uk/04Y6Bo] or contact uml.scholarlycommunications@manchester.ac.uk providing relevant details, so we can investigate your claim.

\section{OPEN ACCESS}




\title{
The Influence of Component Stiffness on the Structure of Multi- thread, Fancy Bouclé Yarn
}

Malek Alshukur ${ }^{1,2}$, Alex Fotheringham ${ }^{1}$ and Hugh Gong $^{3}$

\begin{abstract}
This study examines the relationships between the structure of fancy bouclé yarns and the bending stiffness of the input threads that are used to make those fancy yarns. Four fancy bouclé yarns and an extra two confirmation bouclé yarns were made to test the impact of the bending stiffness of the effect input threads. Six fancy yarns were made to test the impact of bending stiffness of the core thread on the fancy yarn structure. The structure of the fancy yarn was defined by using the Number of Fancy Profiles, the Size of Fancy Profile, the Circularity Ratio of Fancy Profile and the Shape Factor of Fancy yarn. It was found that increasing the value of the stiffness of the effect thread increased the Size of Fancy Profile but decreased the Number of Fancy Profiles and the Shape Factor of Fancy Yarn. Those relationships were represented by regression models that were significant at $\alpha=0.10$. The deviation between the theoretical values and the real values was $-14.39 \%$ and $2.07 \%$. Further, up to a value of $8.636 \mathrm{~g} \mathrm{~mm}^{2}$, the bending stiffness of the core thread appeared not to have an effect on the structure of the fancy yarns. This study is important as it is the first that accounts statistically for the impact of bending stiffness of the input threads on the structure of the resultant fancy yarns. Therefore, it aids fancy yarn manufacturers when designing fancy yarns with predicted structures.
\end{abstract}

Keywords: yarn stiffness; bouclé yarn structure; fancy yarn

\footnotetext{
${ }^{1}$ School of Textiles and Design, Heriot-Watt University, Galashiels, UK

${ }^{2}$ Department of Mechanical Engineering of Textile Industries and Their Technologies, Faculty of Mechanical and Electrical Engineering, Damascus University, Damascus, Syria

${ }^{3}$ School of Materials, The University of Manchester, Manchester, UK
} 


\section{Introduction}

Bending stiffness, or flexural rigidity, is an important mechanical property of textiles because it, amongst other factors, affects their processability while processing or conversion from fibres or filaments to yarns, fabrics and clothes. It is believed that bending stiffness of fibres and filaments plays an important part in the arrangement of fibres or filaments in a yarn, thus contributing to shaping yarn structure. For example, the bending stiffness of yarn is linked to compression and ease of deforming that yarn around thread guides and in attaining precise fabric geometry ${ }^{1}$. It also affects the properties and behaviour of those different forms of textiles while in use ${ }^{1}$.

In a fabric form, bending stiffness affects buckling, drape and handle of fabrics and clothes ${ }^{2,3}$. Additionally, it has an impact on their tailorability, formability and adaptability to the various mechanical forces and on deformation during sewing ${ }^{2}$. Furthermore, bending stiffness contributes to the crease resistance of fabrics and their recovery from crease ${ }^{2,3}$. Shape instability of knitted and woven fabrics is also related to bending stiffness ${ }^{4}$. When there is a contact between the human skin and a fabric made of fibres of low stiffness, fibre tops projecting from such a fabric are responsible for the soft feel ${ }^{1}$ and low scratchiness of such a fabric ${ }^{1}$. It is understood that increasing the thickness of a spun yarn without changing the type of material may result in a similar increase in the bending stiffness of such a yarn ${ }^{1,5}$.

Fancy yarns are unusual types of textiles and have some industrial applications in making furnishings, curtains, upholstery, carpets and floor coverings, wall coverings, covers for car seating and plane seating, trims of furnishing articles, etc. Bending stiffness of raw textile fibres is believed to have an influence on shaping the effect profiles of fancy yarns when making those fancy yarns from drafted fibre strands, e.g.

${ }^{1}$ School of Textiles and Design, Heriot-Watt University, Galashiels, UK ${ }^{2}$ Department of Mechanical Engineering of Textile Industries and Their Technologies, Faculty of Mechanical and Electrical Engineering, Damascus University, Damascus, Syria

${ }^{3}$ School of Materials, The University of Manchester, Manchester, UK 
slivers or rovings ${ }^{6}$. In a study, it was observed that a thick, and stiff, core thread gave a strong base to support the effect profiles and made them protrude over the fancy yarn surface when making bouclé yarns and similar fancy yarns from drafted fibres ${ }^{7}$. However, the aforementioned study was descriptive rather than being based on a rigorous scientific approach. It would have been more useful if the authors had taken into account a wide range of fibre types, measured the bending stiffness of those fibres, selected a wide range of fibre bending stiffness, used a wide range of fibre lengths, included the type of the spinning system used, and the stages of the manufacturing process.

Bending stiffness of input yarns was also thought to be important in defining the shape of the effect profiles of fancy yarns that have multiple-thread structure ${ }^{8}$. It was reported that a favourable fancy gimp yarn structure was achieved by choosing a material type for the effect thread that is sufficiently stiff. As it was found, using a relatively stiff bamboo ply yarn instead of a similar, but less stiff, cotton ply yarn created smaller non-gimp profiles, decreased their number and forced them to have a lower circularity ratio ${ }^{8}$. However, the authors did not use a method to measure the bending stiffness of the input yarns. Instead, they provided a subjective judgement on the bending stiffness of the input yarns. It was also thought that the variation of bending stiffness of the effect thread(s) of boucle yarns may be important because such variation may be reflected in a similar variation in the bouclé profile characteristics, i.e. size, number and circularity ${ }^{9}$.

To address the shortfalls of previous studies on the impact of stiffness of input threads on fancy yarn structure, the bending stiffness of various yarns was measured and used to investigate such an impact numerically. Therefore, a precise relationship ${ }^{1}$ School of Textiles and Design, Heriot-Watt University, Galashiels, UK ${ }^{2}$ Department of Mechanical Engineering of Textile Industries and Their Technologies, Faculty of Mechanical and Electrical Engineering, Damascus University, Damascus, Syria

${ }^{3}$ School of Materials, The University of Manchester, Manchester, UK 
between the structure of multi-thread fancy yarns and the stiffness of their input core and effect threads was achieved.

\section{Materials and Methods}

Measuring the bending stiffness of the input yarns was accomplished using the QuasiStatic Beam Method ${ }^{4,10}$ with a bending frame that has a fixed support and a simple support as shown in Figure 1 (a). A similar approach, but with a different bending frame configuration was used previously ${ }^{4}$. The input yarns were considered as statically indeterminate beams and were left to bend under their own weight. Following this, a digital camera was used to take images of the bent yarns. Those images were analysed using "analySIS FIVE ${ }^{\circledR,}$ software to determine the coordinates of the point of maximum deflection by converting from pixel into distance. These coordinates were used to measure the values of bending stiffness (EI may also be called B) of the input yarns using the following set of equations ${ }^{11}$

$$
\begin{gathered}
E I y=-\frac{1}{24} w x^{4}+\frac{1}{6} A_{y} x^{3}-\frac{1}{2} M_{A} x^{2} \\
A_{y}=\frac{5}{8} w L ; M_{A}=\frac{1}{8} w L^{2}
\end{gathered}
$$

\section{Where $w$ is weight per unit length of yarn, $L$ is length of yarn, $y$ is the vertical distance}

and $x$ is horizontal distance as shown in Figure 1 (b).

\section{- - - please insert Figure 1 here -}

Twenty specimens were used for each input yarn. Before measuring the bending stiffness (in $\mathrm{g} \mathrm{mm}^{2}$ ), the input yarns were preconditioned and then conditioned

${ }^{1}$ School of Textiles and Design, Heriot-Watt University, Galashiels, UK ${ }^{2}$ Department of Mechanical Engineering of Textile Industries and Their Technologies, Faculty of Mechanical and Electrical Engineering, Damascus University, Damascus, Syria

${ }^{3}$ School of Materials, The University of Manchester, Manchester, UK 
according with the BSI ISO 139:2005 Standard. The input yarns were taken from the standard atmosphere when making the final bouclé and bouclé-like yarns, i.e. gimp yarns, wavy yarns and overfed fancy yarns.

The fancy and bouclé yarns of this study were made on a Gemmill and Dunsmore \#3 hollow-spindle machine (UK). The fancy yarns were preconditioned and then conditioned according with the BSI ISO 139:2005 Standard. Following this, the fancy yarns were assessed using the objective methods and the quality parameters, as introduced previously 12,13 . These objective methods indicated that the quality parameters of interest for this kind of fancy yarn are:

- the Number of Fancy Profiles $\left(\mathrm{dm}^{-1}\right)$, which is the number of the bouclé and semibouclé profiles in the unit length of the bouclé yarn;

- the Size of Fancy Profile $\left(\mathrm{mm}^{2}\right)$ which is the area of an ultimate, fitted polygon drawn to match the circumference of the projection of a bouclé and semi-bouclé profiles when seen under a microscope; and

- the Shape Factor of Fancy Yarn $\left(\mathrm{mm}^{2} \mathrm{dm}^{-1}\right)$, which is obtained by multiplying the average area of the profiles by the average number of the profiles. This parameter accounts for the visual and aesthetic Absolute Fancy Bulkiness of Bouclé Profiles.

To conform to the objective methods of assessment of fancy yarn ${ }^{12,13}$, sampling was carried out according to procedures approved by ISO standards (ISO 6939:1988(en)). Additionally, the samples were selected using the systematic approach of sampling ${ }^{14}$. Further, to count the number of the fancy profiles, the sample size was 15 and the sampling pitch was $2 \mathrm{~m}$. To measure the size of the fancy profiles, the sample size was 30 and the sampling distance was $20 \mathrm{~cm}$. This size was the area of an ultimate, fitted

\footnotetext{
${ }^{1}$ School of Textiles and Design, Heriot-Watt University, Galashiels, UK ${ }^{2}$ Department of Mechanical Engineering of Textile Industries and Their Technologies, Faculty of Mechanical and Electrical Engineering, Damascus University, Damascus, Syria

${ }^{3}$ School of Materials, The University of Manchester, Manchester, UK
} 
polygon drawn to match the circumference of the projection of bouclé and semi-boucle profiles when seen under a microscope as indicated by the objective methods of assessment of fancy yarn ${ }^{12,13}$. Drawing such a fitted polygon was conducted using the image analysis software "analySIS FIVE ${ }^{\circledR}$ ".

To test the influence of bending stiffness of the effect input threads on the structure of bouclé yarns, four fancy yarns were made using four input threads. Two effect threads were used to help obtain the correct bouclé profile. The results were confirmed by making two extra bouclé yarns. In all runs of this experiment, the same materials were used for the binder and the core component. However, the effect threads were changed from a run to another as given in Table 1 . The delivery speed of the hollow-spindle machine was DS=30 $\mathrm{m} \mathrm{min}^{-1}$, the supply speed was $\mathrm{SS}=60 \mathrm{~m} \mathrm{~min}^{-1}$ and the rotational speed was $\mathrm{RS}=6600 \mathrm{rpm}$. Thus, the number of wraps was $\mathrm{W}=\mathrm{RS} / \mathrm{DS}=$ $6600 / 30=220 \mathrm{wpm}$ while the overfeed ratio was $\eta=\mathrm{SS} / \mathrm{DS}=(60 / 30) \times 100=200 \%$.

---- please insert Table 1 here --

To test the influence of the bending stiffness of the core input thread on the structure of bouclé yarn, six bouclé yarns were made using three input threads. The effect was a three-ply bamboo thread having a resultant linear density $\mathrm{R} 74 / 3$ tex $(\mathrm{Ne}=$ 24/3). The binder was a 14.5/77 tex nylon multi-filament. The core was altered from a bouclé yarn to another as shown in Table 2. The supply speed of the effect thread was $\mathrm{SS}=46 \mathrm{~m} \mathrm{~min}^{-1}$. The rotational speed of the hollow-spindle was $\mathrm{RS}=6600 \mathrm{rpm}$. The delivery speed of the resultant boucle yarns was DS=35 $\mathrm{m} \mathrm{min}^{-1}$. The overfeed ratio was $\eta=\mathrm{SS} / \mathrm{DS}=(64 / 35) \times 100 \approx 183 \%$. The number of wraps $\mathrm{W}=\mathrm{RS} / \mathrm{DS}=6600 / 35 \approx 188$ wpm. The trials were randomised as given in Table 2 .

- - - Please insert Table 2 here - - -

\footnotetext{
${ }^{1}$ School of Textiles and Design, Heriot-Watt University, Galashiels, UK ${ }^{2}$ Department of Mechanical Engineering of Textile Industries and Their Technologies, Faculty of Mechanical and Electrical Engineering, Damascus University, Damascus, Syria

${ }^{3}$ School of Materials, The University of Manchester, Manchester, UK
} 
The selection of input yarns for the effect component and the core component for the first experiment and the second experiment, respectively, was based on an attempt to obtain input materials with distinct values of bending stiffness regardless of the type of material used. Further, it was our intention to demonstrate that the total value of bending stiffness of an input yarn is more important for the boucle yarn structure than the individual characteristics of the component fibres such as fibre length, fibre fineness, the number of fibres, etc. However, this attempt does not overlook the importance of fibre length and stiffness when making fancy loop yarns ${ }^{6}$, the importance of the amount of yarn twist when making fancy snarl yarns ${ }^{6}$ or the importance of the combination of yarn thickness and twist when making fancy spiral yarns and fancy corkscrew yarns ${ }^{15}$. As far as can be ascertained, such properties of the individual fibres were not as important as the properties of the input yarns and condition of manufacture for the case of fancy bouclé yarns. For example, the change in the core thread tension on the spinning zone changed the bouclé yarn structure remarkably ${ }^{16}$. Additionally, the changes in the geometry of the effect thread in the spinning zone also changed the structure of the ultimate fancy bouclé yarn remarkably when two different material were used ${ }^{17,18}$. A more elaborate approach to understand the effect of the various properties of fibre on the final bouclé structure may be more suited to fancy bouclé yarns made from drafted fibres rather than the case of this study where the bouclé yarns were made using traditional spun yarns. Therefore such as study is beyond the scope of this study as this study is concerned with the relationships between input yarns and the final fancy yarn structure.

\footnotetext{
${ }^{1}$ School of Textiles and Design, Heriot-Watt University, Galashiels, UK ${ }^{2}$ Department of Mechanical Engineering of Textile Industries and Their Technologies, Faculty of Mechanical and Electrical Engineering, Damascus University, Damascus, Syria

${ }^{3}$ School of Materials, The University of Manchester, Manchester, UK
} 


\section{Results and Analysis}

\section{Influence of Bending Stiffness of the Effect Threads}

Figure 2 demonstrates that when the bending stiffness was increased, the average value of Size of Fancy (Bouclé) Profile also increased. Raising the stiffness of the effect threads from 1.579 to $18.3 \mathrm{~g} \mathrm{~mm}^{2}$ led to an increase in the Size of Fancy (Bouclé) Profile from 14.74 to $18.88 \mathrm{~mm}^{2}$. However, Figure 3 demonstrates that the number of bouclé profiles approximately halved from 14 to 6 profiles per decimetre. The total impact of those changes was approximately a $41 \%$ (i.e. $88 \mathrm{~mm}^{2} \mathrm{dm}^{-1}$ ) reduction in the Shape Factor of Fancy (Bouclé) Yarn as shown in Figure 4. These changes in the Shape Factor of Bouclé Yarn were attributed to a reduction in the Number of Fancy (Bouclé) Profiles. This is because the gain in the area of bouclé projections (which is a positive contribution to the bouclé yarn structure) had a weaker impact than the loss in the number of the profiles (which is a negative contribution to the bouclé yarn structure). Therefore, the value of the Shape Factor of Fancy (Bouclé) Yarn decreased when using stiffer effect threads. In practice, this meant that stiffer effect threads reduced the Absolute Fancy Bulkiness of Fancy (Bouclé) Profiles.

- - - please insert Figure 2 here --

- - - please insert Figure 3 here --

- - - please insert Figure 4 here --

Figure 2, Figure 3 and Figure 4 demonstrate that the relationships between the quality parameters of bouclé yarn and the bending stiffness of the effect threads were represented by quadratic regression models as follows:

${ }^{1}$ School of Textiles and Design, Heriot-Watt University, Galashiels, UK ${ }^{2}$ Department of Mechanical Engineering of Textile Industries and Their Technologies, Faculty of Mechanical and Electrical Engineering, Damascus University, Damascus, Syria

${ }^{3}$ School of Materials, The University of Manchester, Manchester, UK 


$$
\begin{gathered}
A=13.62+0.6797\left(B_{e}\right)-0.02145\left(B_{e}\right)^{2} \\
\delta=16.18-1.471\left(B_{e}\right)+0.05127\left(B_{e}\right)^{2} \\
S h F=227.1-14.48\left(B_{e}\right)+0.4775\left(B_{e}\right)^{2}
\end{gathered}
$$

Where: $\mathrm{A}$ is the Size of Boucle Profile, measured in $\mathrm{mm}^{2} ; \delta$ is the Number of bouclé Profiles, measured in dm; $\mathrm{ShF}$ is the Shape Factor of Fancy (Bouclé) Yarn, measured in $\mathrm{mm}^{2} \mathrm{dm}^{-1}$; and $\mathrm{B}_{\mathrm{e}}$ is the bending stiffness of the effect thread.

The statistical study of those regression models is given in Table 3. This table indicates that the linear terms of relationships (3), (4) and (5) were all significant because the corresponding $p$-values were all smaller than $\alpha=0.10$. Further, those regression models had high theoretical accuracy due to the high values of Coefficient of Determination $\mathrm{R}^{2}$ and adjusted $\mathrm{R}^{2}$ which indicated strong relationships between the responses' values and the terms included in the regression models. Due to the quadratic terms, the regression lines were approximately fitting to the actual data and the regression models had low levels of variability of measurements around the regression lines. However, the quadratic terms were all not significant, so the previous three relationships highlighted in Figure 2, Figures 3 and 4 can be represented by linear regression models. Furthermore, the overall significance of models (3) and (4) were secured because the resulting p-values of the simple One-way ANOVA testing were smaller than $\alpha=0.10$. However, the relationship between the Shape Factor of Fancy (Bouclé) Yarn and the bending stiffness of the effect threads can be significant only by using a linear analysis approach. By doing so, model (5) became:

$$
\operatorname{ShF}=203.1-4.606\left(B_{e}\right)
$$

\footnotetext{
${ }^{1}$ School of Textiles and Design, Heriot-Watt University, Galashiels, UK ${ }^{2}$ Department of Mechanical Engineering of Textile Industries and Their Technologies, Faculty of Mechanical and Electrical Engineering, Damascus University, Damascus, Syria

${ }^{3}$ School of Materials, The University of Manchester, Manchester, UK
} 
However, the accuracy of the prediction was reduced because $S E=14.15 \mathrm{~mm}^{2} \mathrm{dm}^{-1}, \mathrm{R}^{2}$ $=90.5 \%$ and $R^{2}(\operatorname{adj})=85.8 \%$.

- - - please insert Table 3 here - - -

\section{Influence of the Bending Stiffness of the Core thread}

The results of this experiment are given in Figure 5, Figure 6 and Figure 7. These three figures did not show any clear or significant difference between the fancy yarns when assessed using the One-Way ANOVA testing. Figure 5, which shows the 95\% confidence intervals for the Size of Bouclé Profile, indicates that the p-value of the ANOVA test was 0.221 . Therefore, these differences were statistically not significant.

- - - please insert Figure 5 here - - -

Figure 6, which identifies the 95\% confidence intervals for the Number of Bouclé Profiles, indicates that the p-value of the ANOVA testing was 0.289. Therefore, the bouclé yarns appeared to have statistically similar numbers of bouclé and semibouclé profiles per decimetre.

- - - please insert Figure 6 here --

Figure 7, which identifies the $95 \%$ confidence intervals for the Circularity Ratio of Bouclé Profile of the bouclé yarns, indicates that the p-value of the ANOVA testing was 0.880 . Therefore, the bouclé profiles of the bouclé yarns were statistically similar in terms of their circularity.

- - - please insert Figure 7 here - - -

\footnotetext{
${ }^{1}$ School of Textiles and Design, Heriot-Watt University, Galashiels, UK ${ }^{2}$ Department of Mechanical Engineering of Textile Industries and Their Technologies, Faculty of Mechanical and Electrical Engineering, Damascus University, Damascus, Syria

${ }^{3}$ School of Materials, The University of Manchester, Manchester, UK
} 


\section{Discussion}

\section{Understanding the impact of bending stiffness of the input thread}

The results of this experiment related to the effect thread may be explained in light of observing of the First Spinning Zone. This zone is located between the first drafting rollers and the mouth of the hollow spindle of the machine ${ }^{9}$. Thus, the results related to the Size of Bouclé Profile were explained by considering the nature of bending. The effect thread(s) usually bends in the First Spinning Zone to form helices around the core thread. When the effect thread(s) was relatively stiff, the thread(s) did not bend easily in order to make the helices. Instead, it bent in a relatively large arc, so wide helices have resulted. Therefore, the resulting bouclé profiles were relatively large in size. Furthermore, this bending behaviour of the effect thread(s) was also restricted by the length of the effect thread(s) in the First Spinning Zone. Due to the constant overfeed ratio, a relatively stiff effect(s) thread was thought to have bent in only a few places along its axis. Consequently, a low number of helices have resulted, so large fancy profiles were made on the ultimate bouclé yarn. In contrast, a softer effect thread(s) have bent in several places along its axis to form more helices. Since the overfeed ratio was constant, a softer effect thread(s) made a higher number of narrower helices than a stiffer effect thread(s). Consequently, more smaller bouclé profiles were made on the ultimate fancy yarn. Moreover, the mechanism of making the bouclé profiles from the effect-thread helices in the Second Spinning Zone, which is located within the hollow spindle, were as follows:

The binder pressed the effect thread(s) to the core thread in the Second Spinning Zone in order to combine them all together. However, because of the helical

\footnotetext{
${ }^{1}$ School of Textiles and Design, Heriot-Watt University, Galashiels, UK ${ }^{2}$ Department of Mechanical Engineering of Textile Industries and Their Technologies, Faculty of Mechanical and Electrical Engineering, Damascus University, Damascus, Syria

${ }^{3}$ School of Materials, The University of Manchester, Manchester, UK
} 
configuration of the effect thread(s), the binder-imposed pressure on the effect thread(s) only at their points of contact, force them to bend again. Subsequently, remaining sections of the effect-thread helices were free of pressure, and therefore, formed the fancy profiles.

When the effect thread(s) was soft, it was thought to have had several potential points for bending. Therefore, due to the binder pressure in the Second Spinning Zone, the helices of the soft effect thread(s) bent and deformed in more than one place simultaneously (Figure 8: a). Consequently, they formed relatively small bouclé profiles in those sections. However, the stiff effect thread(s) was more resistant to the pressure of the binder and to bending. Therefore, it only bent properly at the points that had locally low value of bending stiffness. Those points were sufficiently less resistant to bending than the remaining segments of the stiff effect thread(s) (Figure 8: b). Those weak points existed because of the variability of bending stiffness.

\section{- - - please insert Figure 8 here --}

The bouclé yarn made using the relatively stiff effect threads had large bouclé profiles in a few segments of the yarn while the other segments were compact (Figure 8: b). This is because the lengths of effect threads in the compact segments were sufficiently stiff to resist the pressure of the binder. Therefore, when it bent, it made shallow arcs with high values of curvature. The resulting fancy profiles in the compact segments were waves, arcs, corrugations, and spirals. The extra lengths of the effect threads needed to form larger fancy profiles, in the sections free of the binder pressure, migrated from the neighbouring compact sections on the fancy yarn. The spiralling configuration of the binder within the hollow spindle and the forward movement of the

\footnotetext{
${ }^{1}$ School of Textiles and Design, Heriot-Watt University, Galashiels, UK ${ }^{2}$ Department of Mechanical Engineering of Textile Industries and Their Technologies, Faculty of Mechanical and Electrical Engineering, Damascus University, Damascus, Syria

${ }^{3}$ School of Materials, The University of Manchester, Manchester, UK
} 
intermediate product of fancy yarn within the hollow spindle helped to form the migration phenomenon.

The bending stiffness of the core thread did not have any impact on the final fancy yarn structure over the range of values of bending stiffness used for this study. This is because these core yarns were flexible enough to conform to the pressure of both the effect thread and the multifilament binder with in the spinning zone of the machine while making the intermediate product. In the end, the influence of the core thread was found to be weak. Consequently, these core threads only supported the structure without affecting it. The variation observed in the results of this yarn may be attributed to the machine vibration and to random variation.

\section{Model Testing and Confirmations of the Results}

The accuracy of the regression models 3,4 and 5 was tested practically by making and testing two extra bouclé yarns. A comparison between theoretical values and the actual values is given in Table 4. The deviations in the value of ShF were calculated and were: $9.79 \%$ and $-14.39 \%$ for the first and the second confirmation yarns, respectively.

$$
\text { - - - please insert Table } 4 \text { here - - - }
$$

The deviation for those two confirmation bouclé yarns is acceptable, though it was relatively high for the second yarn. This is because the fancy yarn structure is already based on deliberate variation. Additionally, the variation in bending stiffness of the effect threads used to make the confirmation cones was high, i.e. the CV was 32.97 $\%$ and $35.7 \%$ for the effect threads of the first and second confirmation yarns,

\footnotetext{
${ }^{1}$ School of Textiles and Design, Heriot-Watt University, Galashiels, UK ${ }^{2}$ Department of Mechanical Engineering of Textile Industries and Their Technologies, Faculty of Mechanical and Electrical Engineering, Damascus University, Damascus, Syria

${ }^{3}$ School of Materials, The University of Manchester, Manchester, UK
} 
respectively. Further, there is the impact of variability of the machine. Therefore, deviation up to $15 \%$ from the predicted values was also accepted.

\section{Subjective Assessment and Morphological Study of the Bouclé Yarns}

Figure 9 shows images of the bouclé yarns made when testing the bending stiffness of the effect thread, including the two confirmation yarns. It is inferred from this figure that as the bending stiffness of the effect threads increased, the boucle structure changed its morphology from having a high number of bouclé profiles to a low number of bouclé profiles. Further, the number of wavy or sigmoidal sections increased by increasing the stiffness of the input threads. Furthermore, clustered bouclé profiles appeared when using the softest (for yarn I-1) and the stiffest (for yarn I-4) effect threads.

$$
\text { - - - please insert Figure } 9 \text { here -- }
$$

Figure 10 shows images of the bouclé yarns made when testing the bending stiffness of the core thread. Regardless of colours, this figure shows that the boucle yarns were similar in structure and morphological appearance, though the input threads were different in material type and bending stiffness. Further, the fancy profiles of yarns II-1, II-2, II-3, II-4, II-5 and II-6 were combinations of bouclé profiles, semi-bouclé profiles, sigmoidal sections, a few loops and a few wavy sections. Additionally, the size and number of the bouclé and semi-bouclé profiles appeared to be similar. Although the section of yarn II-4 initially appeared to show a lower number of profiles than the other yarns, this section, in reality, has 6 bouclé profiles but 2 of them were projecting horizontally underneath the lens of the camera that was used to take the photos.

$$
\text { - - - please insert Figure } 10 \text { here - - - }
$$

\footnotetext{
${ }^{1}$ School of Textiles and Design, Heriot-Watt University, Galashiels, UK ${ }^{2}$ Department of Mechanical Engineering of Textile Industries and Their Technologies, Faculty of Mechanical and Electrical Engineering, Damascus University, Damascus, Syria

${ }^{3}$ School of Materials, The University of Manchester, Manchester, UK
} 


\section{Conclusions}

Based on this study, it was concluded that:

- An eleven times increase in the value of bending stiffness of the effect threads (from 1.579 to $18.3 \mathrm{~g} \mathrm{~mm}^{2}$ ), increased the average Size of Bouclé Profile significantly by approximately $4 \mathrm{~mm}^{2}$. However, it reduced the average Number of Bouclé Profiles significantly from 14 to only 7 profile per $\mathrm{dm}$.

- Those changes in the area and number of bouclé profiles were reflected as a reduction to the Absolute Fancy Bulkiness of Bouclé Profiles by $85 \mathrm{~mm}^{2} \mathrm{dm}^{-1}$ as measured by the Shape Factor of Bouclé Yarn.

- Therefore, the stiffer the effect threads, the lower the Number of Bouclé Profiles (and semi-boucle profiles), the greater the Size of Boucle Profile, and the lower the value of the Shape Factor of Fancy (Bouclé) Yarn.

- However, over the values used, the bending stiffness of the core thread did not affect the structure of multi-thread bouclé yarn. The differences observed between these yarns made to test the influence of stiffness of the core thread may be attributed to the machine vibration and to random variation.

\section{References}

1. Lawrence CA. Fundamentals of spun yarn technology. New York: CRC Press LLC, 2003.

2. Park J-W and Oh A-G. Bending Rigidity of Yarns Textile Research Journal. 2006; 76: 478-85.

3. Morton WE and Hearle JWS. Physical properties of textile fibres. 4 ed. Cambridge, England: Woodhead Publishing Limited, 2008.

${ }^{1}$ School of Textiles and Design, Heriot-Watt University, Galashiels, UK

${ }^{2}$ Department of Mechanical Engineering of Textile Industries and Their Technologies, Faculty of Mechanical and Electrical Engineering, Damascus University, Damascus, Syria

${ }^{3}$ School of Materials, The University of Manchester, Manchester, UK 
4. Ghane M, Sheikhzadeh M, Halabian AM and Khaburi S. Bending Rigidity of Yarn Using a Two Supports Beam System. FIBRES \& TEXTILES in Eastern Europe. 2008; 16: 30-2.

5. Goswami BC, Martindale JG and Scardino FL. Textile Yarn: Technology, Structure, and Applications. New York: John Wiley \& Sons, 1977.

6. Gong RH and Wright RM. Fancy yarns: Their manufacture and application. Cambridge, The UK: Woodhead Publishing Limited, 2002.

7. Mole K and Knox JS. The Properties and Uses of Specific Hollow-spindle Yarns. Journal of The Textile Institute. 1989; 80: 441-53.

8. Alshukur $\mathrm{M}$ and Fotheringham A. Quality and structural properties of gimp fancy yarns using the Design of Experiments. Journal of The Textile Institute. 2015; 106: 490-502.

9. Alshukur M. On the Structure of Multi-thread Bouclé Yarn. School of Textiles and Design. Galashiels: Heriot-Watt University, February 2017.

10. Elder HM and El-Tawashi M. Some Bending Measurements on Yarns. The Journal of The Textile Institute. 1977; 68: 188-9.

11. Beer FP, Johnston ER and Dewolf JT. MECHANICS OF MATERIALS. 4 ed. New York, the USA: McGraw-Hill, 2006.

12. Alshukur M. The Quality of Fancy Yarn: Part I: Methods and Concepts. International Journal of Textile and Fashion Technology. 2013; 3: 11-24.

13. Alshukur M. The Quality of Fancy Yarn: Part II: Practical Experiments and Application. International Journal of Textile and Fashion Technology. 2013; 3: 25-38.

14. Groebner DF, Shannon PW, Fry PC and Smith KD. Business Statistics: A Decision-Making Approach 6ed.: Prentice-Hall Publishing Company, Inc., 2005.

15. Meadwell ES. An Exploration of Fancy Yarn Creation. the Graduate Faculty of North Carolina State University. North Carolina: North Carolina State University, 2004, p. 185.

16. Alshukur M and Sun D. Effect of core thread tension on structure and quality of multi-thread bouclé yarn. Indian Journal of Fibre \& Textile Research. 2016; 41: 36772.

17. Alshukur M and Yurchenko D. Experimental study on the spinning geometry of multi-thread fancy yarn on hollow-spindle spinning machines: Part I. International Journal of Clothing Science and Technology. 2017; accepetd.

18. Alshukur M and Yurchenko D. Experimental study on the spinning geometry of multi-thread fancy yarn on hollow-spindle spinning machines: Part II. International Journal of Clothing Science and Technology. 2017; accepted.

\footnotetext{
${ }^{1}$ School of Textiles and Design, Heriot-Watt University, Galashiels, UK

${ }^{2}$ Department of Mechanical Engineering of Textile Industries and Their Technologies, Faculty of Mechanical and Electrical Engineering, Damascus University, Damascus, Syria

${ }^{3}$ School of Materials, The University of Manchester, Manchester, UK
} 


\section{List of Tables}

Table 1: Material Used to Test the Importance of Bending Stiffness of the Effect Thread and their Properties

\begin{tabular}{|c|c|c|c|c|c|c|}
\hline \multirow{2}{*}{\multicolumn{2}{|c|}{$\begin{array}{l}\text { Function of Input } \\
\text { Yarn }\end{array}$}} & \multirow{2}{*}{$\begin{array}{l}\text { Material } \\
\text { Types }\end{array}$} & \multirow{2}{*}{$\begin{array}{l}\text { Linear } \\
\text { Density }\end{array}$} & \multirow{2}{*}{$\begin{array}{l}\text { Number of } \\
\text { Input Yarns }\end{array}$} & \multicolumn{2}{|c|}{ Bending Stiffness $\mathrm{B}\left(\mathrm{g} \mathrm{mm}^{2}\right)$} \\
\hline & & & & & Average & $\begin{array}{l}\text { Standard } \\
\text { Deviation }\end{array}$ \\
\hline \multicolumn{2}{|c|}{ Core component } & $\begin{array}{l}\text { Cotton/ } \\
\text { lambswool }\end{array}$ & R $120 / 2$ & 1 & 3.662 & 1.774 \\
\hline \multicolumn{2}{|c|}{ Binder component } & $\begin{array}{l}\text { Nylon multi- } \\
\text { filament }\end{array}$ & $14.5 / 77$ & 1 & Not important & Not important \\
\hline \multirow{6}{*}{ 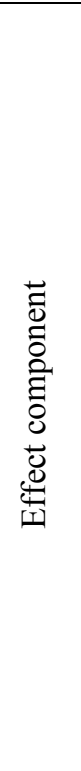 } & Yarn I-1 & Cotton & R $126 / 3$ & 2 & 1.579 & 0.774 \\
\hline & Yarn I-2 & Lambswool & R $120 / 2$ & 2 & 2.518 & 0.966 \\
\hline & Yarn I-3 & Natural wool & R $195 / 2$ & 2 & 5.249 & 1.601 \\
\hline & Cone I-4 & Stiff acrylic & 140 & 2 & 18.3 & Not given \\
\hline & $\begin{array}{l}\text { Confirmation } \\
\text { Yarn } 1\end{array}$ & $\begin{array}{l}\text { Wool/ } \\
\text { polyamide }\end{array}$ & R $120 / 2$ & 2 & 3.183 & 1.671 \\
\hline & $\begin{array}{l}\text { Confirmation } \\
\text { Yarn } 2\end{array}$ & $\begin{array}{l}\text { Lambswool/ } \\
\text { viscose }\end{array}$ & R $120 / 2$ & 2 & 3.835 & 1.033 \\
\hline
\end{tabular}

${ }^{1}$ School of Textiles and Design, Heriot-Watt University, Galashiels, UK ${ }^{2}$ Department of Mechanical Engineering of Textile Industries and Their Technologies, Faculty of Mechanical and Electrical Engineering, Damascus University, Damascus, Syria

${ }^{3}$ School of Materials, The University of Manchester, Manchester, UK 
Table 2: Material Used to Test the Impact of Bending Stiffness of the Core Thread and Their Properties

\begin{tabular}{|l|l|l|l|l|l|}
\hline Bouclé Yarn & Trial Order & Core Thread & Linear Density & $\begin{array}{l}\text { Bending } \\
\text { Stiffness }\end{array}$ & $\begin{array}{l}\text { SD of Bending } \\
\text { Stiffness }\end{array}$ \\
\hline Yarn II-1 & 1 & Material & (tex) & $\left(\mathbf{g ~ m m}^{2} \mathbf{)}\right.$ & $\mathbf{( g ~ m m}^{2} \mathbf{)}$ \\
\hline Yarn II-2 & 3 & lambswool & 83 & 0.549 & 0.229 \\
\hline Yarn II-3 & 5 & linen/cotton & R144/2 & 2.029 & 0.872 \\
\hline Yarn II-4 & 6 & lambswool/viscose & R120/2 & 3.835 & 1.033 \\
\hline Yarn II-5 & 4 & natural wool & R195/2 & 5.249 & 0.154 \\
\hline Yarn II-6 & 2 & wool/cotton & R163/2 & 8.636 & 4.324 \\
\hline
\end{tabular}

${ }^{1}$ School of Textiles and Design, Heriot-Watt University, Galashiels, UK

${ }^{2}$ Department of Mechanical Engineering of Textile Industries and Their Technologies, Faculty of Mechanical and Electrical Engineering, Damascus University, Damascus, Syria

${ }^{3}$ School of Materials, The University of Manchester, Manchester, UK 
Table 3: The Statistical Study of the Three Regression Models of the Quality

Parameters

\begin{tabular}{|c|c|c|c|c|}
\hline $\begin{array}{l}\text { Regression } \\
\text { Model }\end{array}$ & $\begin{array}{l}\text { Predictor Term } \\
\left(B_{e}\right)\end{array}$ & $\begin{array}{l}\text { P-value of } \\
\text { Sequential } \\
\text { ANOVA Testing }\end{array}$ & $\begin{array}{l}\text { Accuracy of the } \\
\text { Regression Line }\end{array}$ & $\begin{array}{l}\text { P-value of } \\
\text { Simple ANOVA } \\
\text { Testing }\end{array}$ \\
\hline \multirow{2}{*}{$\begin{array}{l}\text { Size of } \\
\text { Bouclé } \\
\text { Profile }\end{array}$} & Linear & 0.032 & \multirow{2}{*}{$\begin{array}{l}\mathrm{SE}=0.18 \mathrm{~mm}^{2} \\
\mathrm{R}^{2}=99.7 \% \\
\mathrm{R}^{2}(\operatorname{adj})=99.1 \%\end{array}$} & \multirow[b]{2}{*}{0.056} \\
\hline & quadratic & 0.141 & & \\
\hline \multirow{2}{*}{$\begin{array}{l}\text { Number of } \\
\text { Bouclé } \\
\text { Profiles }\end{array}$} & Linear & 0.060 & \multirow{2}{*}{$\begin{array}{l}\mathrm{SE}=0.5 \mathrm{dm}^{-1} \\
\mathrm{R}^{2}=99.2 \% \\
\mathrm{R}^{2}(\text { adj })=97.7 \%\end{array}$} & \multirow[b]{2}{*}{0.087} \\
\hline & quadratic & 0.164 & & \\
\hline \multirow{2}{*}{$\begin{array}{l}\text { ShF of } \\
\text { Bouclé } \\
\text { Yarn }\end{array}$} & Linear & 0.049 & \multirow{2}{*}{$\begin{array}{l}\mathrm{SE}=8.8 \mathrm{~mm}^{2} \mathrm{dm}^{-1} \\
\mathrm{R}^{2}=98.1 \% \\
\mathrm{R}^{2}(\mathrm{adj})=94.4 \%\end{array}$} & \multirow[b]{2}{*}{0.136} \\
\hline & quadratic & 0.292 & & \\
\hline
\end{tabular}

${ }^{1}$ School of Textiles and Design, Heriot-Watt University, Galashiels, UK

${ }^{2}$ Department of Mechanical Engineering of Textile Industries and Their Technologies, Faculty of Mechanical and Electrical Engineering, Damascus University, Damascus, Syria

${ }^{3}$ School of Materials, The University of Manchester, Manchester, UK 
Table 4: Results of Testing the Models of Importance of Bending Stiffness of the Effect Thread to the Bouclé Yarn Structure

\begin{tabular}{|c|c|c|c|c|c|c|}
\hline \multirow[b]{2}{*}{$\begin{array}{l}\text { Bouclé } \\
\text { Property }\end{array}$} & \multicolumn{3}{|c|}{$\begin{array}{l}\text { Confirmation Yarn I } \\
B_{e}=3.183 \mathrm{~g} \mathrm{~mm}^{2}\end{array}$} & \multicolumn{3}{|c|}{$\begin{array}{l}\text { Confirmation Yarn II } \\
B_{\mathrm{e}}=3.835 \mathrm{~g} \mathrm{~mm}^{2}\end{array}$} \\
\hline & $\begin{array}{l}\text { Predicted } \\
\text { Value }\end{array}$ & $\begin{array}{l}\text { Actual } \\
\text { Value }\end{array}$ & $\begin{array}{l}\text { Deviation } \\
\text { from the } \\
\text { Predicted } \\
\text { Value \% }\end{array}$ & $\begin{array}{l}\text { Predicted } \\
\text { Value }\end{array}$ & $\begin{array}{l}\text { Actual } \\
\text { Value }\end{array}$ & $\begin{array}{l}\text { Deviation from } \\
\text { the Predicted } \\
\text { Value \% }\end{array}$ \\
\hline $\begin{array}{l}\text { Size of bouclé } \\
\text { profile, } \mathrm{mm}^{2}\end{array}$ & 15.56 & 13.8 & -11.3 & 15.91 & 14.8 & -6.97 \\
\hline $\begin{array}{l}\text { Number of bouclé } \\
\text { profiles, } \mathbf{d m}^{-1}\end{array}$ & 12.02 & 12.27 & 2.07 & 11.29 & 10.33 & -8.5 \\
\hline ShF, $\mathrm{mm}^{2} \mathrm{dm}^{-1}$ & 181.01 & 163.292 & -9.79 & 178.59 & 152.88 & -14.39 \\
\hline
\end{tabular}

${ }^{1}$ School of Textiles and Design, Heriot-Watt University, Galashiels, UK

${ }^{2}$ Department of Mechanical Engineering of Textile Industries and Their Technologies, Faculty of Mechanical and Electrical Engineering, Damascus University, Damascus, Syria

${ }^{3}$ School of Materials, The University of Manchester, Manchester, UK 


\section{List of Figures}

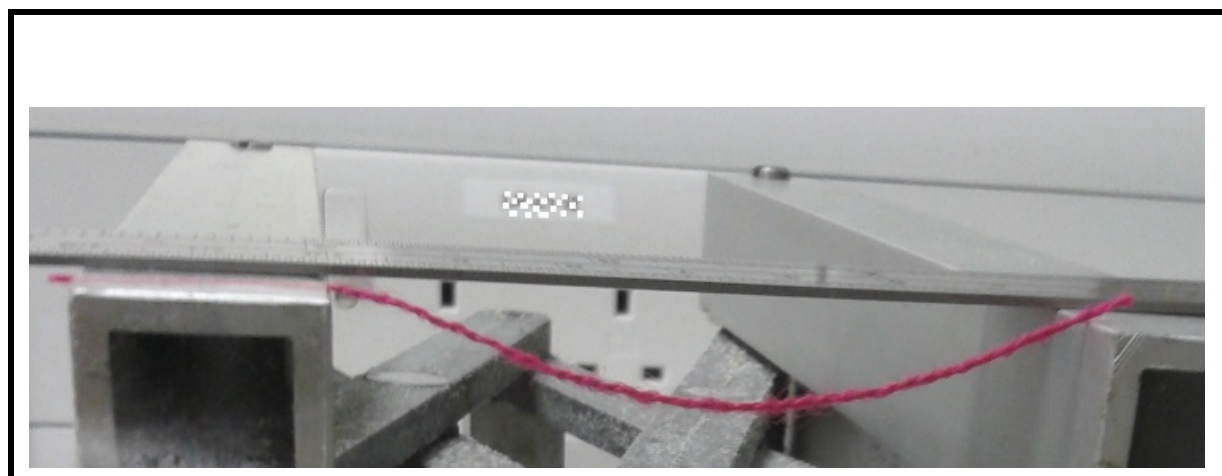

(a) Example of Bent Yarn

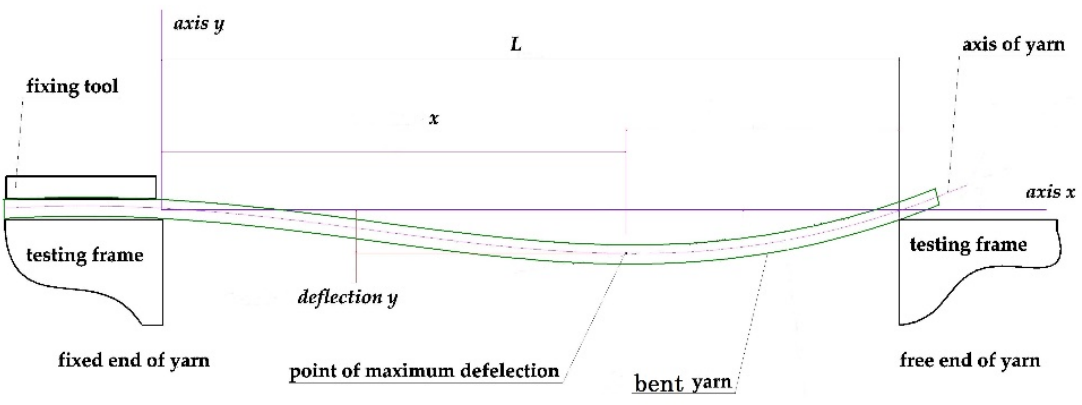

(b) Schematic Illustration of the Input for the Calculation Method

Figure 1: Images of the Bending Frame with a Bent Yarn

${ }^{1}$ School of Textiles and Design, Heriot-Watt University, Galashiels, UK

${ }^{2}$ Department of Mechanical Engineering of Textile Industries and Their Technologies, Faculty of Mechanical and Electrical Engineering, Damascus University, Damascus, Syria

${ }^{3}$ School of Materials, The University of Manchester, Manchester, UK 


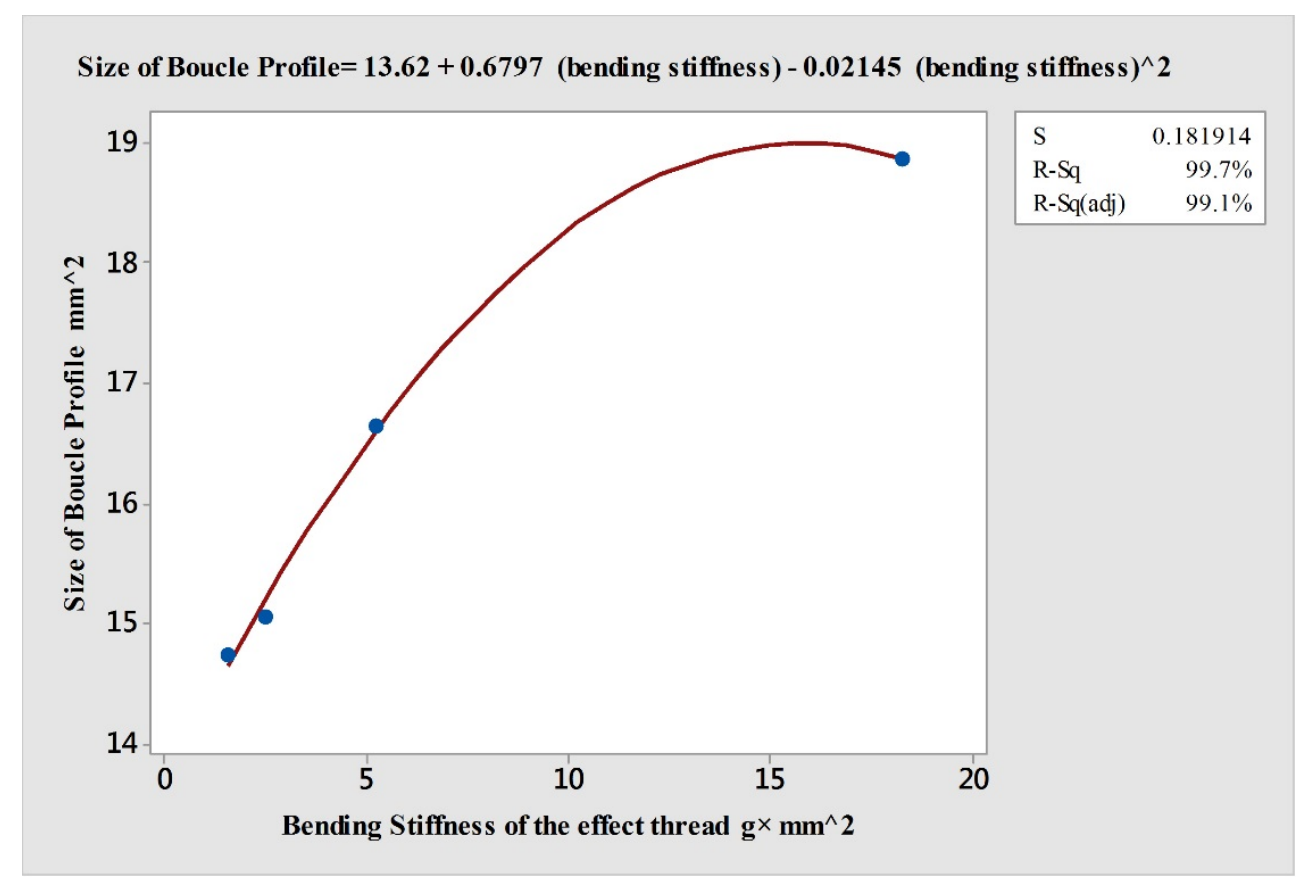

Figure 2: Relationship between the Size of Bouclé Profile and Bending Stiffness of Effect Threads

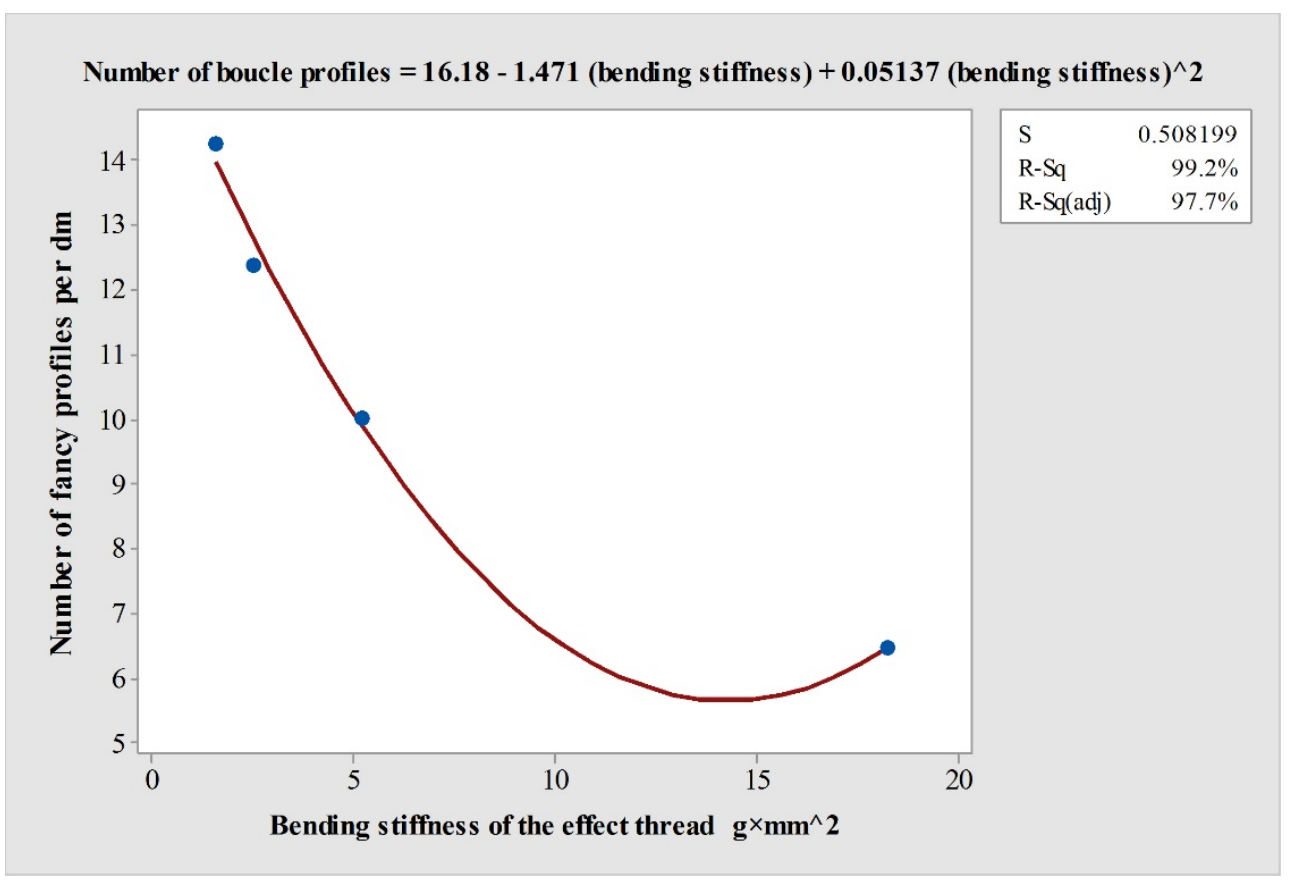

Figure 3: Relationship between the Number of Bouclé Profiles and Bending Stiffness of Effect Threads

${ }^{1}$ School of Textiles and Design, Heriot-Watt University, Galashiels, UK

${ }^{2}$ Department of Mechanical Engineering of Textile Industries and Their Technologies, Faculty of Mechanical and Electrical Engineering, Damascus University, Damascus, Syria

${ }^{3}$ School of Materials, The University of Manchester, Manchester, UK 


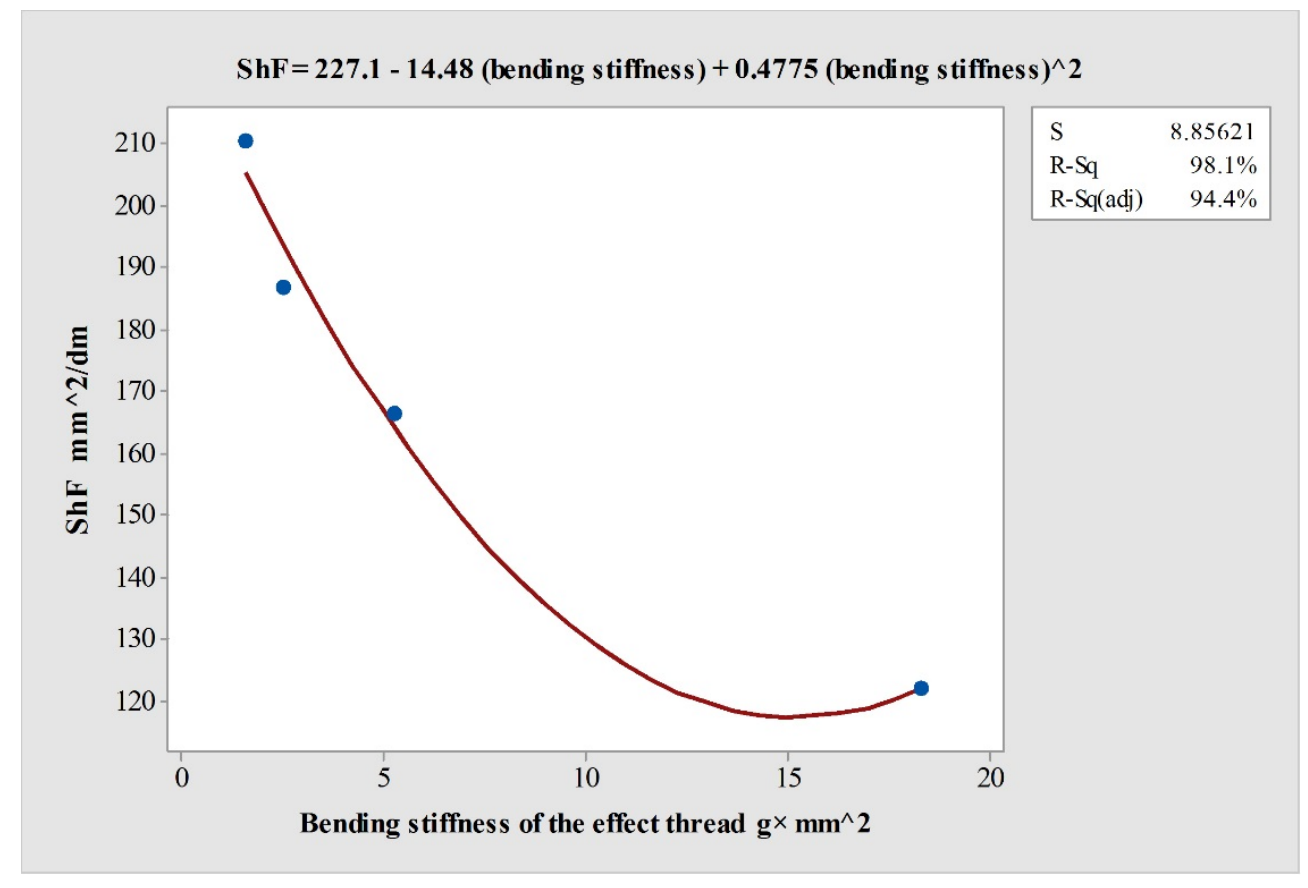

Figure 4: Relationship between the Shape Factor of Bouclé Yarn and Bending Stiffness of Effect Threads

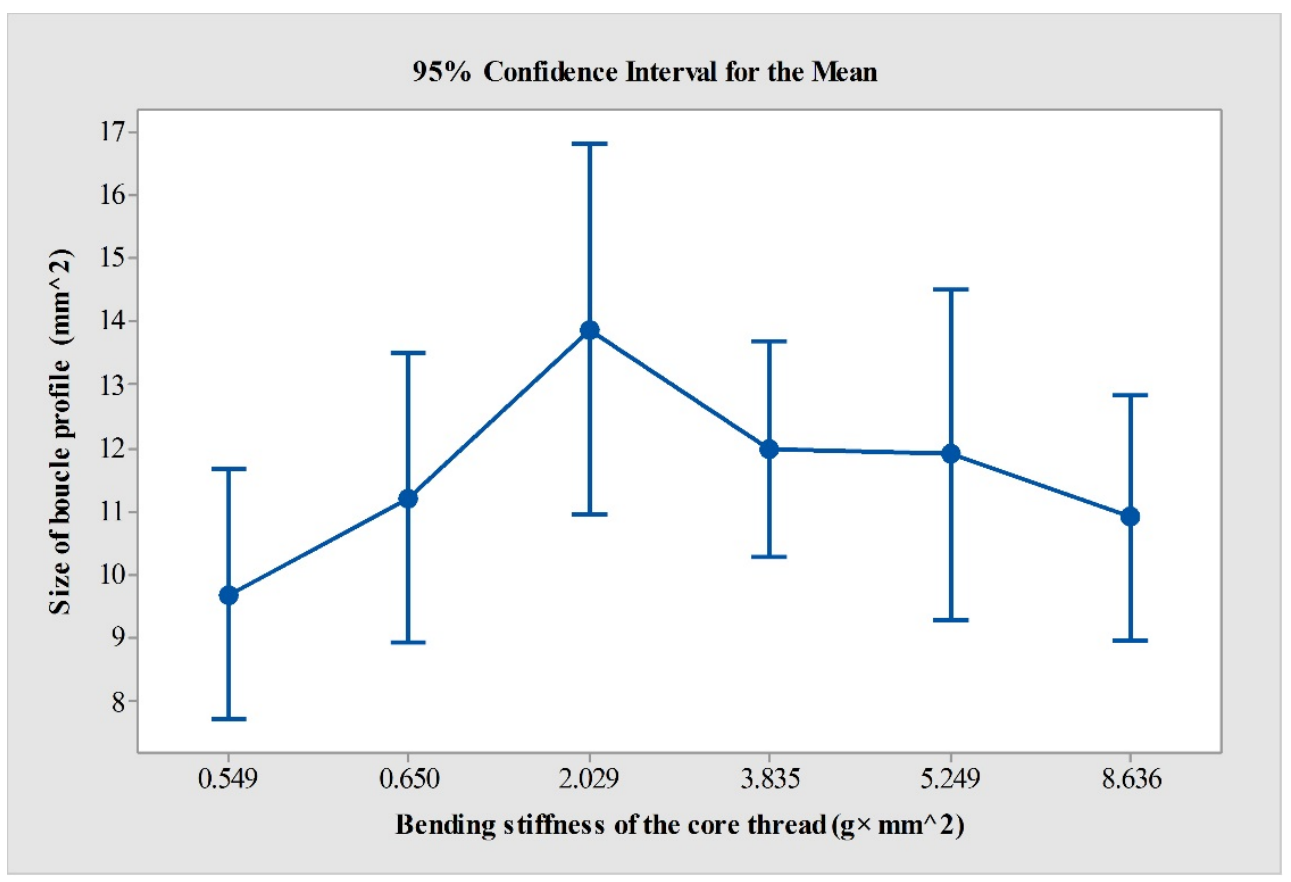

${ }^{1}$ School of Textiles and Design, Heriot-Watt University, Galashiels, UK ${ }^{2}$ Department of Mechanical Engineering of Textile Industries and Their Technologies, Faculty of Mechanical and Electrical Engineering, Damascus University, Damascus, Syria

${ }^{3}$ School of Materials, The University of Manchester, Manchester, UK 
Figure 5: Interval Plot for the Influence of the Bending Stiffness of the Core Thread on the Size of Bouclé Profile

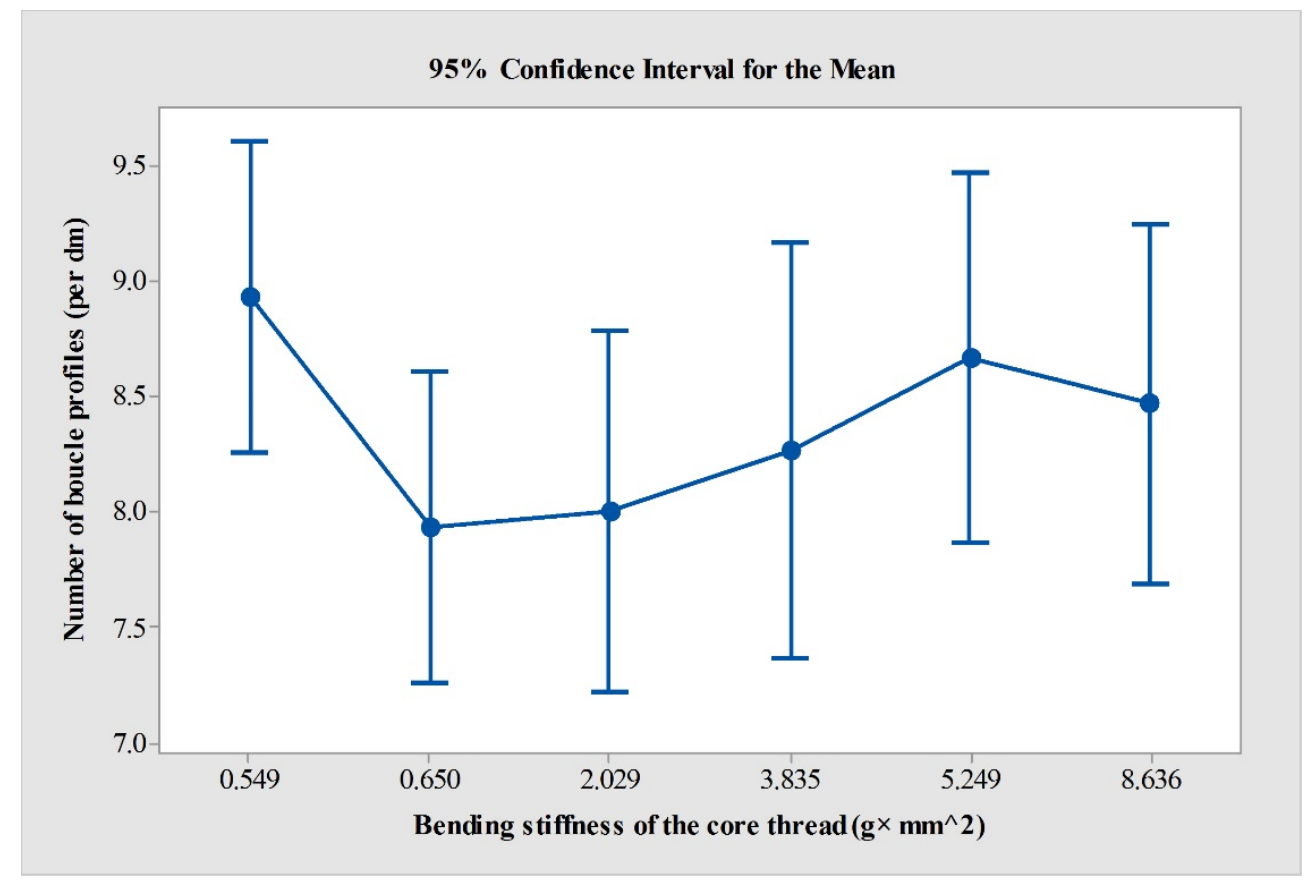

Figure 6: Interval Plot for the Influence of the Bending Stiffness of the Core Thread and the Number of Bouclé Profiles

${ }^{1}$ School of Textiles and Design, Heriot-Watt University, Galashiels, UK

${ }^{2}$ Department of Mechanical Engineering of Textile Industries and Their Technologies, Faculty of Mechanical and Electrical Engineering, Damascus University, Damascus, Syria

${ }^{3}$ School of Materials, The University of Manchester, Manchester, UK 


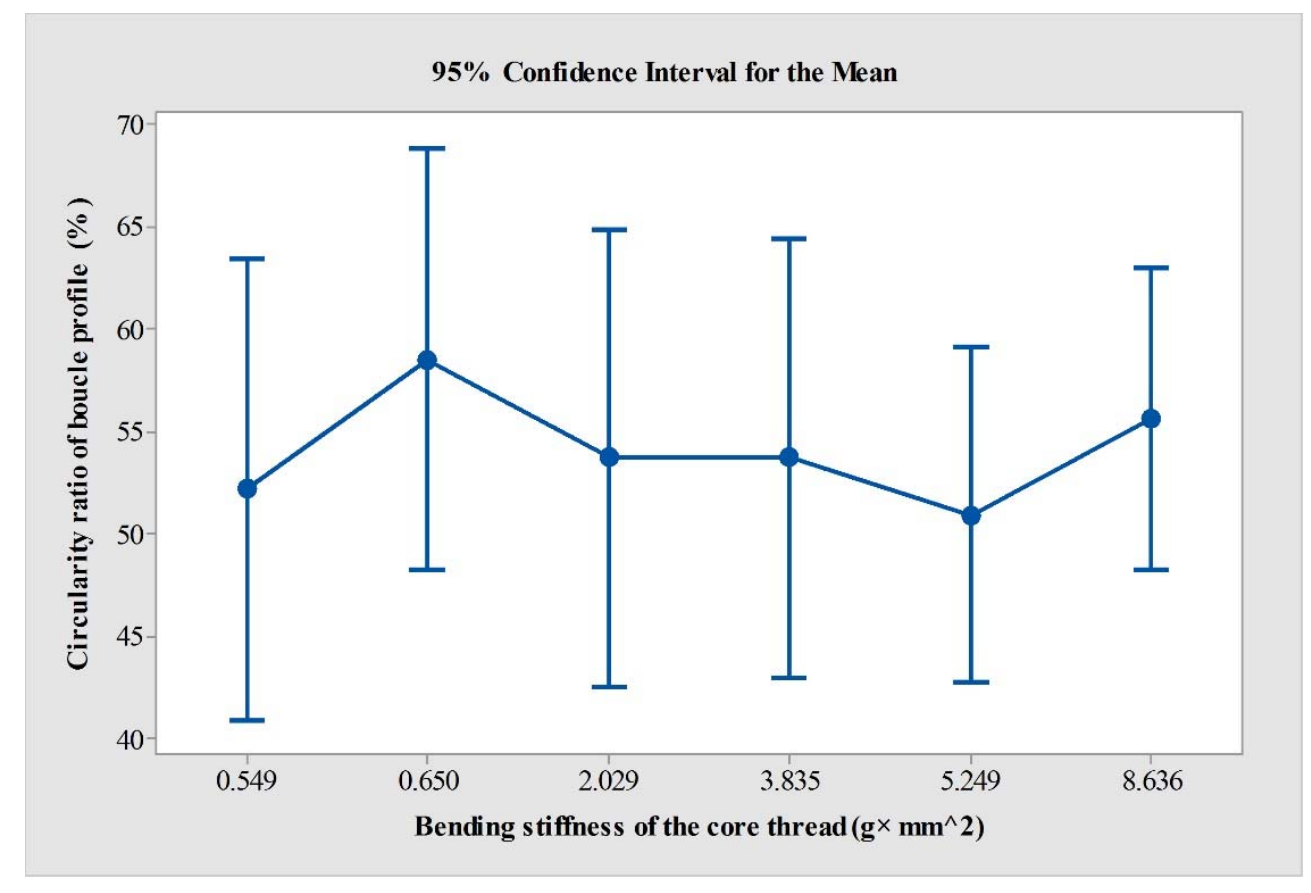

Figure 7: Interval Plot for the Effect of the Bending Stiffness of the Core Thread on the Circularity Ratio of Bouclé Profile

(a)
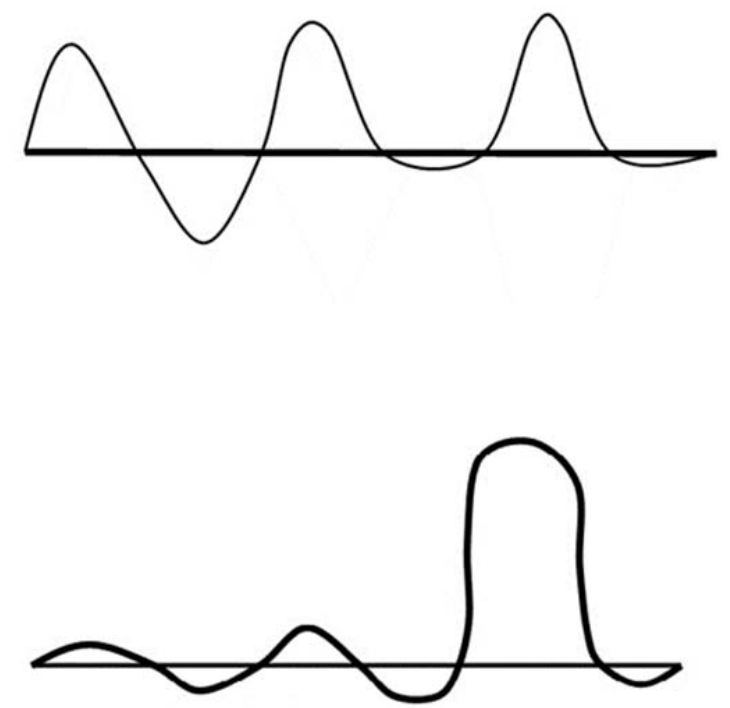

(b)

${ }^{1}$ School of Textiles and Design, Heriot-Watt University, Galashiels, UK

${ }^{2}$ Department of Mechanical Engineering of Textile Industries and Their Technologies, Faculty of Mechanical and Electrical Engineering, Damascus University, Damascus, Syria

${ }^{3}$ School of Materials, The University of Manchester, Manchester, UK 
Figure 8: Deformation of the Effect-thread Helices due to Pressure of the Binder;

(a) Soft Effect Thread; (b) Stiff Effect Thread

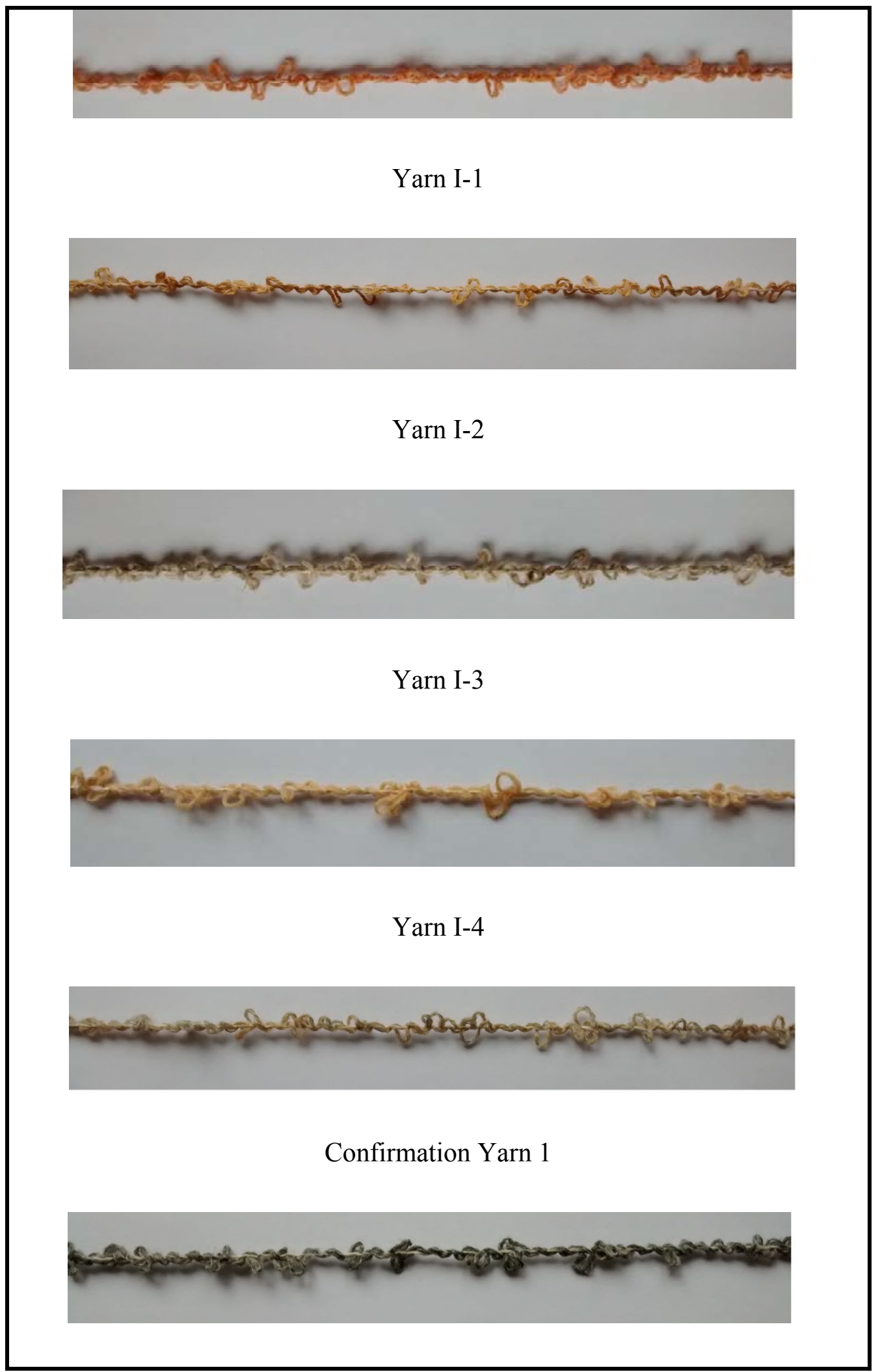

${ }^{1}$ School of Textiles and Design, Heriot-Watt University, Galashiels, UK

${ }^{2}$ Department of Mechanical Engineering of Textile Industries and Their Technologies, Faculty of Mechanical and Electrical Engineering, Damascus University, Damascus, Syria

${ }^{3}$ School of Materials, The University of Manchester, Manchester, UK 


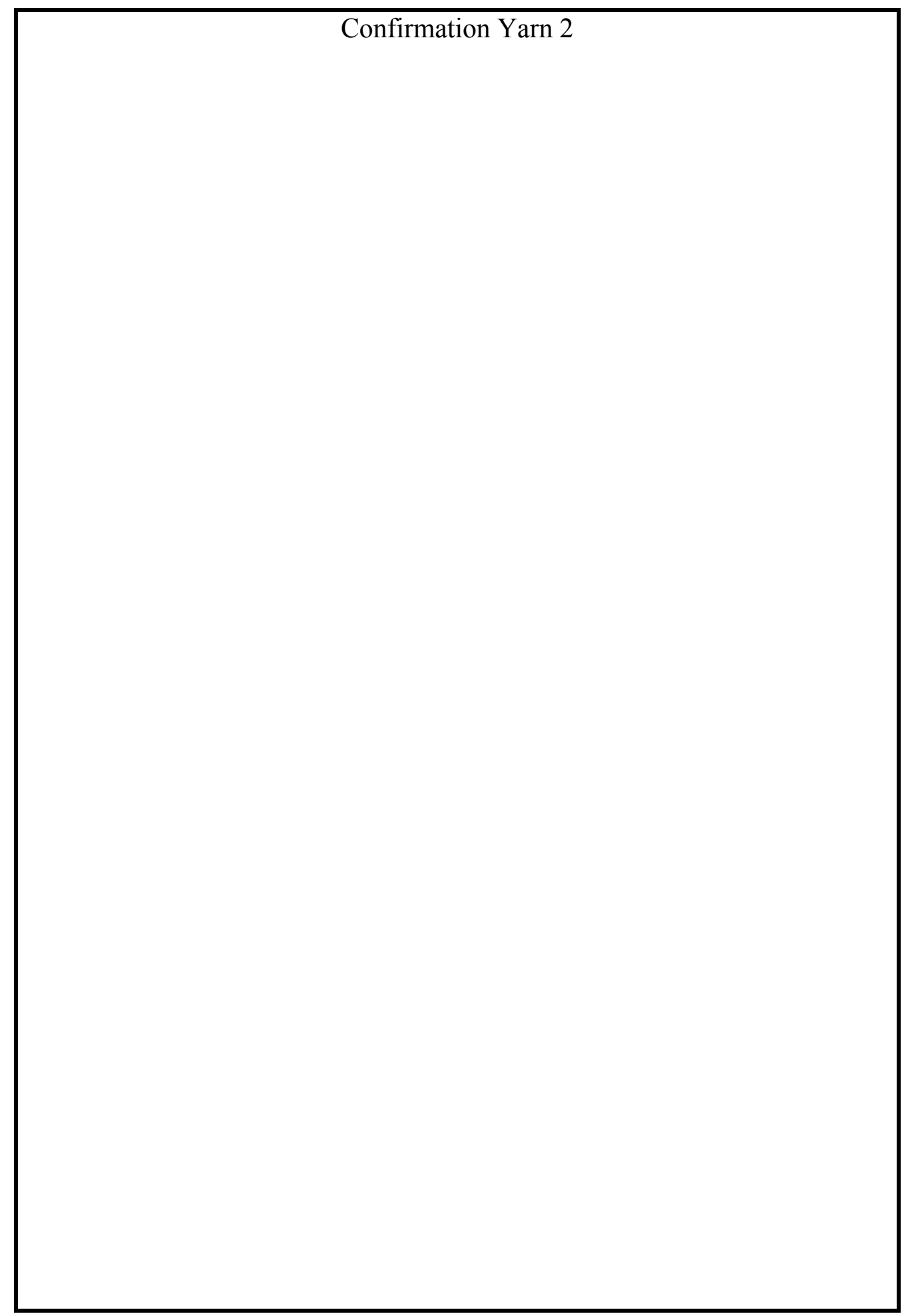

Figure 9: Images of Bouclé Yarns Made to Show the Importance of Bending Stiffness of the Effect Thread to the Bouclé Yarn Structure

${ }^{1}$ School of Textiles and Design, Heriot-Watt University, Galashiels, UK

${ }^{2}$ Department of Mechanical Engineering of Textile Industries and Their Technologies, Faculty of Mechanical and Electrical Engineering, Damascus University, Damascus, Syria

${ }^{3}$ School of Materials, The University of Manchester, Manchester, UK 


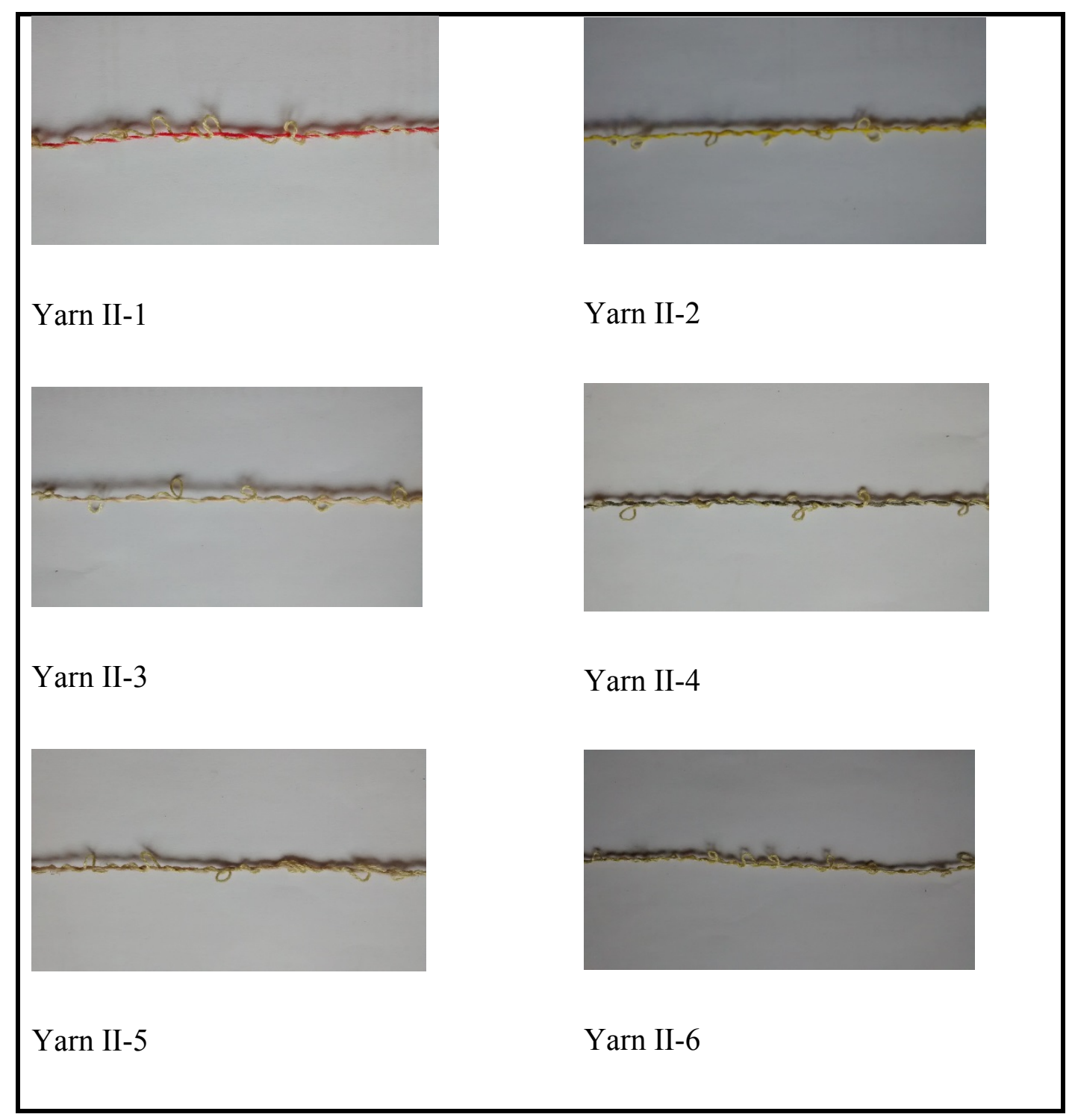

Figure 10: Images of the Bouclé Yarns Made to Test the Influence of the Bending Stiffness of the Core thread on the Structure of Bouclé Yarn

\footnotetext{
${ }^{1}$ School of Textiles and Design, Heriot-Watt University, Galashiels, UK

${ }^{2}$ Department of Mechanical Engineering of Textile Industries and Their Technologies, Faculty of Mechanical and Electrical Engineering, Damascus University, Damascus, Syria

${ }^{3}$ School of Materials, The University of Manchester, Manchester, UK
} 